NBER WORKING PAPER SERIES

\title{
FURTHER COMMENTS ON THE IMPACT OF THE ASIAN MIRACLE ON THE THEORY OF ECONOMIC GROWTH
}

\author{
Robert W. Fogel \\ Working Paper 15721 \\ http://www.nber.org/papers/w15721 \\ NATIONAL BUREAU OF ECONOMIC RESEARCH \\ 1050 Massachusetts Avenue \\ Cambridge, MA 02138 \\ February 2010
}

The views expressed herein are those of the author and do not necessarily reflect the views of the National Bureau of Economic Research.

NBER working papers are circulated for discussion and comment purposes. They have not been peerreviewed or been subject to the review by the NBER Board of Directors that accompanies official NBER publications.

(C) 2010 by Robert W. Fogel. All rights reserved. Short sections of text, not to exceed two paragraphs, may be quoted without explicit permission provided that full credit, including $\odot$ notice, is given to the source. 
Further Comments on The Impact of the Asian Miracle on the Theory of Economic Growth

Robert W. Fogel

NBER Working Paper No. 15721

February 2010

JEL No. F47,O53

\begin{abstract}
$\underline{\text { ABSTRACT }}$
This paper addresses three issues related to the relative rates of growth in the United States, the European Union, and China during the four decades between 2000 and 2040. The first concerns the source of the factors which make it likely that China will continue to grow at a high rate for another generation. The paper argues that this growth will be the result of both favorable economic and political conditions. The second concerns the source of declining GDP growth in the original fifteen nations of the European Union. For these countries, the underlying cause is due in large measure to low fertility rates and an increase in the dependency ratio. The third issue is the projection of long-term U.S. growth in GDP at a rate of 3.7 percent per annum.
\end{abstract}

Robert W. Fogel

Director, Center for Population Economics

University of Chicago, Booth School of Business

5807 S. Woodlawn Avenue, Suite 367

Chicago, IL 60637

and NBER

rwf@cpe.uchicago.edu 


\section{Further Comments on The Impact of the Asian Miracle on the Theory of Economic Growth}

This paper deals with three principal issues raised by some readers of my NBER working paper, The Impact of the Asian Miracle on the Theory of Economic Growth (http://www.nber.org/papers/w14967).

1. Why do I predict that the growth rate of GDP for the EU-15 will be only 1.2 percent per annum between 2000 and 2040?

2. Why do I believe that U.S. GDP between the same years will grow at 3.7 percent per annum?

3. Why am I so optimistic about China's future growth rate, which I put at 8.0 percent per annum between 2000 and 2040?

Let me deal first with my optimistic estimate for China. How and why China will become an economic colossus has to do not only with the country's economics, but also with its politics. To begin with, it helps to divide China's economy into three major components: agriculture, services, and industry. Over the 25 years between 1978 and 2003, the growth of labor productivity has been high in each of these sectors, averaging about 6 percent each year. At the national level, however, output per worker grew by 9 percent annually over the same period. The national growth exceeded the sectoral growth rates because output per worker was much higher in industry and services than it was in agriculture. So as millions shifted from agriculture-where the bulk of China's labor has been concentrated - to industry or services, the country's annual growth rate rose by an additional 3 percentage points. Between 1978 and 2005, about 195 million workers shifted from agriculture to industry and services. In other words, internal migration accounted for about 47 percent of the labor force in industry and services in 2005. I expect such shifts between sectors to continue to be an important element in China's overall economic growth over the next generation (Fogel 2007). 
Many observers believe that social unrest, both active and latent, will retard China's rate of economic growth. Potential pitfalls include the shaky state of the banking system. They also include income disparities between the rapidly growing coastal provinces and the more slowly growing interior provinces, between urban and rural labor, and between highly skilled and manual labor. Other potential flashpoints arise from pressures on fuel supplies and electrical power, the growth of environmental pollution, and the adequacy of water supplies. These problems are well understood by China's leaders and solutions are being actively pursued. So far, the government has managed to head off potential crises.

As a consequence, the polls conducted by reliable agencies reveal a widespread belief among the Chinese that their living conditions have improved and will continue to improve in the future. This optimism reflects the rapid increases in income experienced by the great majority of households for more than a quarter of a century.

Still another possibility is that internal growth will be derailed by international conflicts such as the border disputes over Kashmir with India and Pakistan and disputes over the sovereignty of the Spratly Islands with Malaysia, the Philippines, and Vietnam. But these issues are being treated diplomatically rather than militarily. The most tumultuous dispute, over the sovereignty of Taiwan, now appears to be headed toward a resolution, tentatively endorsed by both China and the incoming KMT government in Taiwan.

An important factor in sustaining China's high growth rate will be its investments in expanding secondary and tertiary education-another key shift likely to boost labor productivity growth. In a 2006 study, I reported that high-school graduates in the United States were 1.8 times as productive, and college-educated workers 3.1 times as productive, as their peers with less than a ninth-grade education. Extrapolating these findings to China, and estimating that the enrollment ratio in high school will grow to about 100 percent and in college to about 50 percent over the next generation, would, in and of 
itself, add over 6 percentage points to the annual growth rate (Fogel 2006).

These targets for higher education are not out of reach. As recently as 1980, Western European nations had tertiary enrollment ratios (the ratio of the number of students in colleges and universities to the total number of persons at college ages, usually 18-22) of about 25 percent; only in the United States was that figure above 50. The movement to from 25 to 50 in Western Europe took place over just two decades at the end of the twentieth century. In the case of Britain, two-thirds of the increase from 19 to 52 percent took place between 1990 and 1997.

The significance of investment in human capital as an engine of economic growth has not eluded the State Council in China. In 1998, Jiang Zemin called for a massive increase in enrollments in higher education, and the response was swift. Over the next four years, enrollment in higher education increased by 165 percent (from 3.4 million to 9.0 million), and the number of students studying abroad rose by 152 percent. Given that the tertiary enrollment ratio increased by about 50 percent between 2000 and 2004 (from 12.5 to 19.0 percent), my projection for 2040 is not overly optimistic. China is already on track to reach it (Fogel 2007).

Next, my forecast for the EU-15. Here, demography is the key issue. What is worrisome is not just the zero rate of population growth (the demographic forecasts are not mine but those of the U.N. population division) but the changes in the age structure of the population.

The population of OECD nations has been aging rapidly, and that trend is likely to continue over the next several decades. Columns 1 and 2 of Table 1 present the forecast of the Population Division of the United Nations on the change in the median age of the five largest West European nations. In Germany, Italy, and Spain, the predicted increases range between 11 and 14 years. In France and the United Kingdom, the median age increases by six and five years, respectively. 
Table 1

Median Age and Percent of Population Age 65 and Over in Five European Nations in 2000 and 2040

\begin{tabular}{|c|c|c|c|c|}
\multirow{2}{*}{ Country } & \multicolumn{2}{|c|}{ Median Age } & \multicolumn{2}{c|}{ Percentage age 65 and over } \\
\cline { 2 - 5 } & 2000 & 2040 & 2000 & 2040 \\
$(1)$ & $(2)$ & $(3)$ & $(4)$ \\
\hline \hline France & 37.7 & 44.2 & 16.1 & 26.5 \\
\hline Germany & 40.0 & 51.2 & 16.4 & 31.8 \\
\hline Italy & 40.3 & 50.9 & 18.4 & 31.8 \\
\hline Spain & 37.6 & 49.1 & 16.8 & 28.1 \\
\hline United Kingdom & 37.7 & 42.3 & 15.9 & 22.6 \\
\hline
\end{tabular}

Source: http://esa.un.org/unpp

Columns 3 and 4 forecast the change in percentage of the population that will be over 65 . For Germany and Italy, the elderly will increase to nearly a third of the population. Only in the United Kingdom will the elderly be less than a quarter of the population.

The basic reason for the rapid aging of the population has been the low level of fertility. In all of these countries, the total fertility rate has been below the level needed to replace their populations for several decades. As a result, the percentage of women in the childbearing ages has declined from about 50 percent in 2000 (it was also about 50 percent in 1950) and is projected to be about 35 percent in 2040. So we have a double whammy (to use American slang): not only will women in the reproductive ages have sharply reduced fertility rates, but the proportion of women who are in the childbearing ages will also have declined sharply (see Table 2).

Attitudes toward sex have evolved sharply. One hundred fifty years ago, it was considered a sin to enjoy sex, the only legitimate purpose for which was procreation. But today, even in Rome, young women respond that sex is mainly a recreational activity. Behind the statistics on trends in fertility is a vast change in ethics embodied in a culture that is much different from that embraced by the generation 
that fought in World War II, which married early and produced the great baby boom of 1945-1965.

Table 2

Percentage of Women Aged 15-49 in 2000 and 2040

\begin{tabular}{|c|c|c|c|}
\multicolumn{1}{|c|}{ Country } & 2000 & 2040 & Percentage decline \\
\hline \hline France & 47.5 & 38.3 & 19 \\
\hline Germany & 46.8 & 34.6 & 26 \\
\hline Italy & 47.0 & 34.4 & 30 \\
\hline Spain & 50.8 & 35.8 & 11 \\
\hline United Kingdom & 46.8 & 41.5 & 27 \\
\hline
\end{tabular}

Source: http://esa.un.org/unpp

The widespread embrace of the ethic that celebrates sex as recreation means that the rate of natural increase (births minus deaths) is likely to decline in the principal EU-15 nations. Indeed, even in 2000 , the natural rate of increase was negative in Germany and Italy. By 2040 , it is likely that natural increase will be negative in all of the designated nations except the United Kingdom (see Table 3). 
Table 3

Predicted Changes in the Natural Rate of Increase (per thousand)

\begin{tabular}{|c|c|c|}
\hline Country & 2000 & 2040 \\
\hline \hline France & 3.8 & -0.3 \\
\hline Germany & -1.5 & -6.2 \\
\hline Italy & -0.7 & -4.3 \\
\hline Spain & 1.4 & -0.9 \\
\hline United Kingdom & 1.3 & 0.7 \\
\hline
\end{tabular}

Source: http://esa.un.org/unpp

Although the twentieth century increase in the share of the population that is elderly is a tribute to the great advances in economic performance, biomedical sciences, and environmental improvements, there is no automatic guarantee of equitable balance between the generations in the future. Indeed, there are new problems that will have to be solved if a third of population in 2040 is over age 65.

Moreover, since younger workers are a major source of new ideas, slowing down the ascendency of the next generation may retard the pace of technological change. The solution to such problems will not be easy. The elderly should not be shunted aside as if they were rotten tomatoes. To force their premature retirement will undermine not only their morale, but also the morale of those who expect to replace them.

As a result of the demographic trends, the dependency ratio is expected to rise sharply in 4 of the 5 largest EU-15 nations between the years 2000 and 2040, as shown by Table 4 . 
Table 4

Predicted Changes in the Dependency Ratio

\begin{tabular}{|c|c|c|c|}
\multicolumn{1}{c|}{ Country } & 2000 & 2040 & Percentage Increase \\
\hline \hline France & .54 & .75 & 39 \\
\hline Germany & .47 & .79 & 65 \\
\hline Italy & .49 & .81 & 57 \\
\hline Spain & .46 & .72 & 19 \\
\hline United Kingdom & .54 & .64 & \multicolumn{2}{|c|}{} \\
\hline
\end{tabular}

Source: http://esa.un.org/unpp (2008 revision)

The inverse of one plus the dependency rates is a reasonable proxy for the labor force participation rate (which I designate by $\rho$ ). Hence, Table 4 suggests an annual rate of decline of 0.4 percent in the labor force participation rate due purely to changes in the age structure of the population. I allow $\rho$ to decline by an additional 0.2 percent per annum because of a reduction in the length of the work year over the period 2000-2040. This allowance raises the annual rate of decline in $\rho$ to 0.6 percent per annum. Since I expect the annual rate of growth in labor productivity of the 5 nations to average about 1.8 percent, it follows that their annual rate of growth in both per capita income and GDP will average 1.2 percent.

Now let me turn to my forecast for the United States. Although the U.S. and EU-15 growth rates were the same during $1975-2005$, I do not believe that to be an overriding consideration. The key issue is the slowness of the EU relative to the U.S. in adopting the new information technology. Other issues are the greater EU preference for leisure than commodities when compared with the U.S., and the decline of the EU's annual rate of growth in labor productivity from 2.4 percent during 1980-1995 to 1.5 percent during 1995-2004. By comparison, U.S. labor productivity growth increased from 1.5 percent per annum during 1980-1995 to 3.0 percent during 1995-2004 (van Ark et al. 2008). 
During 1995-2004, U.S. GDP grew at 3.7 percent per annum. I believe that this high rate will persist down to 2040 because of continuing technological advances in genetic engineering, health care, information technology, transportation, energy production and consumption, and education (van Ark et al. 2008). 
References

Fogel RW. 2006. Why China is likely to achieve its growth objectives. NBER Working Paper w12122.

Fogel RW. 2007. Capitalism and democracy in 2040: Forecasts and speculations. NBER Working Paper w13184.

United Nations. 2009. World population prospects: The 2008 revision population database. Accessed on December 27, 2009 at http://esa/un.org/unpp/p2k0data.asp.

van Ark B, O'Mahony M, Timmer MP. 2008. The productivity gap between Europe and the United States: Trends and causes. Journal of Economic Perspectives 22: 25-44. 